\title{
Biometry of Seeds of Caupi Beans Cream Varieties Cultivated in Northeast Brazil
}

\author{
Neurivan Vicente da Silva ${ }^{1}$, Paulo César Ferreira Linhares ${ }^{2}$, Roberto Pequeno de Sousa ${ }^{2}$, \\ Janilson Pinheiro de Assis ${ }^{2}$, Eudes de Almeida Cardoso ${ }^{2}$, Joaquim Odilon Pereira ${ }^{3}$, Walter Rodrigues Martins ${ }^{3}$, \\ Lunara de Sousa Alves ${ }^{2}$, Mateus de Freitas Almeida dos Santos ${ }^{2}$, Glenda Soares de Lira Rosado Nogueira ${ }^{2}$ \\ \& Jordany Ramalho Silveira Farias ${ }^{3}$ \\ ${ }^{1}$ Universidade Federal de Campina Grande, Pombal, PB, Brazil \\ ${ }^{2}$ Jitirana Research Group, Department of Agronomic and Forestry Sciences, Federal Rural Semi-Arid University, \\ Mossoró, RN, Brazil \\ ${ }^{3}$ Center of Exact and Natural Sciences, Federal Rural Semi-Arid University, Mossoró, RN, Brazil \\ Correspondence: Paulo César Ferreira Linhares, Jitirana Research Group, Department of Agronomic and Forestry \\ Sciences, Federal Rural Semi-Arid University, Mossoró, RN, Brazil. E-mail: paulolinhares@ufersa.edu.br
}

Received: June 1, 2019 Accepted: February 6, $2020 \quad$ Online Published: March 15, 2020

doi:10.5539/jas.v12n4p239 URL: https://doi.org/10.5539/jas.v12n4p239

\begin{abstract}
Biometric analysis is of great importance for the evaluation of the characteristics of the seeds, being used to predict the physiological aspect. In this context, the objective was to study the biometry of seeds of cowpea bean varieties cultivated by family farmers in the Brazilian Northeast. The work was carried out from April to July 2018, consisting of the harvesting of cowpea bean seeds in the agroecological production area, of the region of Apodi, Northeast Brazil. A completely randomized design with six treatments (owl, canapum, lizão, always green, cow's rib plus cultivar BRS potiguar) and six replicates of 100 seeds was used. A completely randomized design with six treatments and six replicates of 100 seeds was used. The evaluated characteristics were: length and width of seeds, expressed in $\mathrm{mm}$; length/width ratio of seeds, expressed in $\mathrm{mm}$; weight of one hundred seeds, expressed in $\mathrm{g}$; weight of one thousand seeds, expressed in grams and quantity of seeds per kg, expressed in units $\mathrm{kg}^{-1}$. There was a statistical difference between the varieties of cowpea for the biometric characteristics studied. The cowpea variety was statistically superior to the others, for the characteristics, seed length $(11.37 \mathrm{~mm})$, length $(2.14 \mathrm{~mm})$ length ratio, weight of one hundred seeds $(31.16 \mathrm{~g})$ and weight of one thousand seeds $(312.46 \mathrm{~g})$. The BRS potiguar variety was statistically superior to the characteristic number of seeds per kilo (5099.16 units kg-1 $)$.
\end{abstract}

Keywords: biometric analysis, length/width, weight seeds, varieties of cowpea beans

\section{Introduction}

Cowpea (Vigna unguiculata (L.) Walp.) is a staple in the Brazilian diet. It is of great importance, because it is an affordable source of proteins, with a high energy value. In low-income populations, it exerts a social function to meet the nutritional needs of this part of the population (Locatelli et al., 2014).

It has center of origin the African continent, being introduced in Brazil in the middle of century XVI, in the state of Bahia, expanding to the other regions of the country (Embrapa Meio-Norte, 2018).

In the Rio Grande do Norte, Northeast of Brazil, the average productivity is $171 \mathrm{~kg} \mathrm{ha}^{-1}$ (CONAB, 2016), low values due to the edaphoclimatic conditions of the region (Almeida, 2016).

The use of seeds of high physiological quality is a factor of relevance, since these are contained innovations and technological advances, which adds value to the product transferred to the farmer, representing strong economic gains to the agricultural sector (Brazil, 2011).

In this context, the study of seed biometry is of paramount importance for the determination of physiological quality, being used in the multiplication of different plant species (Alves et al., 2005). According to Marcos Filho (2005), the seed has attributes of great importance as biological organism and agricultural input. It leads the genetic characteristics determining the performance of the cultivar, being responsible for establishing the desired stand, providing the basis for profitable production (Marcos Filho, 2005). 
Seed is the main input in agricultural crop production systems, its physiological quality being the main factor responsible for the stand and the vigor of the plants in the field, through the knowledge of the weight and morphological patterns of the seeds it is possible to a strategy to maximize the standardization of emergence of the seedlings, providing greater productivity in the crops (Carvalho \& Nakagawa, 2000).

Given the importance of studying biometric traits as a way of differentiating native varieties of cowpea, in relation to the physical aspects of the seed, the objective was to study the biometry of seeds of cowpea bean varieties cultivated in the Brazilian Northeast.

\section{Materials and Methods}

\subsection{Study Area}

The work was carried out from April to July 2018, consisting of the harvesting of cowpea bean seeds in the agroecological production area, of the region of Apodi, Northeast Brazil.

Samples of the five varieties of cowpea (owl, canapun, lizão, always green and cow rib) were collected at the agroecological farm of Mr. Golinha, Apodi region, Brazil, in June 2018, in soil classified as cambisol (Empraba, 2006).

Soil samples were collected to a $0-20 \mathrm{~cm}$ in the agroecological farm with bean production, being layer and then sent to be processed and analyzed in the UFERSA Water, Soil and Plant Analysis Laboratory, providing the following results: $\mathrm{pH}$ (water 1:2.5) $=8.00$; exchangeable cations $\mathrm{Ca}=47.6 \mathrm{cmolc} / \mathrm{dm}^{3} ; \mathrm{Mg}=10.9 \mathrm{cmolc} / \mathrm{dm}^{3} ; \mathrm{K}=$ $75.9 \mathrm{mg} / \mathrm{dm}^{3} ; \mathrm{Na}=36.1 \mathrm{mg} / \mathrm{dm}^{3} ; \mathrm{P}($ Mehlich $)=13.5 \mathrm{mg} / \mathrm{dm}^{3} ;$ organic matter $=6.4 \mathrm{~g} / \mathrm{kg}$ and N $=1.26 \mathrm{~g} / \mathrm{kg}$.

The commercial seed sample (cultivar BRS Potiguar) was purchased by EMATER-Technical Assistance and Rural Extension Company of Rio Grande do Norte in April 2018, referring to the harvest of 2017.

According to Kottek et al. (2006) and the classification of Köppen, the local climate is BSwh', dry and very hot, the dry season being normally from June to January, and a rainy season being from February to May. The average annual rainfall is $673.9 \mathrm{~mm}$ and the average relative humidity is $68.9 \%$.

\subsection{Statistical Delineation and Treatments}

A completely randomized design (DIC) with six treatments and six replicates of one hundred seeds was used. The treatments consisted of five creole varieties of cowpea (owl, canapum, lizão, always green and cow's rib plus cultivar BRS potiguar).

The biometric analysis was carried out at Department of Agronomic and Forestry Sciences, Federal Rural Semi-Arid University (UFERSA), being evaluated the following characteristics: length and width of seed (performed with samples of one hundred seeds per replicate, using a digital caliper, expressed in $\mathrm{mm}$ ); length/width ratio (performed by the quotient of the length by width); weight of one hundred seeds (Obtained by counting 100 units of dry grains weighed in a precision balance of $0.01 \mathrm{~g}$, expressed in grams); weight of one thousand seeds (carried out with eight subsamples of 100 seeds which had their dry biomass weighed in a scale with $0.001 \mathrm{~g}$ precision, being the results expressed in grams (Brazil, 2011) and seed quantity per $\mathrm{kg}$, the number of seeds per kilogram was determined).

Analyses of variance were conducted for the evaluated characteristics using the ESTAT software (Kronka \& Banzato, 1995). Tukey's test at $(\mathrm{p}<0.05)$ probability was used for comparisons between cowpea cultivars.

\section{Results and Discussion}

It was observed a statistical difference at the level of $\mathrm{P}<0.01$ of probability for the characteristics seed length, seed width, seed length and width ratio, weight of one hundred seeds, weight of one thousand seeds and seed quantity per kilo for varieties cowpea (owl, canapum, lizão, always green, cow rib and the commercial cultivar BRS potiguar) (Table 1). 
Table 1. Values of $\mathrm{F}$ of analysis of variance (ANAVA) for seed length, expressed in mm (SL); seed width, expressed in $\mathrm{mm}(\mathrm{SW})$; length and width of seed ratio, expressed in $\mathrm{mm}(\mathrm{LW})$; weight of one hundred seeds, expressed in g (WS); weight of one thousand seeds, expressed in g (W100S) and number of seeds per kilogram, expressed in unit $\mathrm{kg}^{-1}$ (SK) of five varieties of Creole seeds plus BRS cultivar of cowpea cultivated in Northeastern Brazil

\begin{tabular}{llllllll}
\hline Causes of variation & CV & SL & SW & LW & WS & W100S & SK \\
\hline Varieties & 5 & $326.6^{* *}$ & $652.8^{* *}$ & $801.6^{* *}$ & $41.03^{* *}$ & $40.17^{* *}$ & $46.04^{* *}$ \\
Residue & 30 & - & - & - & - & - & - \\
CV $(\%)$ & - & 1.48 & 1.10 & 1.64 & 5.58 & 5.67 & 5.97 \\
Average Overall & - & 9.5 & 5.9 & 1.6 & 26.2 & 262.0 & 3904.6 \\
Total & 35 & - & - & - & - & - & - \\
\hline
\end{tabular}
Note. $* *: \mathrm{P}<0.01$.

For the characteristic seed length, the evergreen and lizão varieties do not differ from each other, since the owl, canapum, cow rib and the commercial cultivar BRS potiguar differ from each other at $\mathrm{p}<0.05$ of the varieties always green and lizão. The Creole cow rib variety was statistically superior to all varieties, with an average length of $11.37 \mathrm{~mm}$ (Table 2).

In study by Nascimento et al. (2012) with cowpea seeds, presented seed length with variations from 5.72 to 11.16 $\mathrm{mm}$, with a mean of $7.69 \mathrm{~mm}$. Data close to the average found in this study, being of $9.5 \mathrm{~mm}$.

In the characteristic seed width, statistically, all varieties differ from each other. The values found ranged from 4.98 $\mathrm{mm}$ for the commercial cultivar BRS potiguar, being the lowest value, and $6.89 \mathrm{~mm}$ for the canapum variety, being the highest value. With this performance the Creole canapum variety stands out over the others when it comes to the characteristic width (Table 3).

Similar values were found in a study by Melo et al. (2011), where the highest mean presented was of the LESP-10 line, $8.82 \mathrm{~mm}$ wide.

Table 2. Seed length, expressed in $\mathrm{mm}$ (CS) and seed width, expressed in $\mathrm{mm}$ (DS) as a function of native varieties and BRS cultivar of cowpea, cultivated in Northeast Brazil

\begin{tabular}{lll}
\hline Varieties of cowpea beans & Seed length (SL) & Seed width (LS) \\
\hline Owl & $9.92 \mathrm{~b}$ & $5.78 \mathrm{~d}$ \\
Canapum & $8.52 \mathrm{e}$ & $6.89 \mathrm{a}$ \\
Lizão & $9.19 \mathrm{c}$ & $6.26 \mathrm{~d}$ \\
Always green & $9.16 \mathrm{c}$ & $6.12 \mathrm{c}$ \\
Cow's rib & $11.37 \mathrm{a}$ & $5.37 \mathrm{e}$ \\
BRS potiguar & $8.78 \mathrm{~d}$ & $4.98 \mathrm{f}$
\end{tabular}

Note. $*$ Means followed by the same letter in the column do not differ by Tukey test at the 5\% probability level.

There was no statistically significant difference in the length/width ratio characteristic for the evergreen and lizão varieties, as well as for the owl and commercial BRS cultivars, while the canapum and cow ribs varieties differ from each other and from the other varieties.

In this characteristic, the canapum variety is the one-to-one ratio, that is, $1.24 \mathrm{~mm}$, which is characterized as a globular (rounded) seed having its length very close to the width. In the cow rib variety, the ratio was $2.14 \mathrm{~mm}$, being the one that distances the ratio from one to 1, which is characterized as being a reniform (long) seed (Table 3).

For the weight of one hundred seeds among the cowpea varieties, cow ribs were significantly superior to all other varieties, with mean values of $25.50 \mathrm{~g} / 100$ seeds (owl variety); $27.00 \mathrm{~g} / 100$ seeds (canapun variety); $25.66 \mathrm{~g} / 100$ seeds (variety); $28.33 \mathrm{~g} / 100$ seeds (always green variety); $31.16 \mathrm{~g} / 100$ seeds (cow rib variety) and $19.66 \mathrm{~g} / 100$ seeds (BRS potiguar) (Table 4).

The most recent classification for grain size was proposed by Freire Filho et al. (2012), whose grain weights vary with values less than $10 \mathrm{~g}$ (extra-small grains) to more than 30 grams (extra grains). In general, most cultivars 
range from $15 \mathrm{~g}$ to $25 \mathrm{~g}$, with higher concentrations in the bands of $15 \mathrm{~g}$ and $20 \mathrm{~g}$ per 100 grains (Freire Filho et al., 2011). The data of this research showed that the varieties presented weight of 100 grains within the range of 15 to $25 \mathrm{~g}$, except for the cow rib variety, which presented extra grains (31.16 g/100 seeds).

Freitas (2015) when evaluating the genetic potential of traditional varieties of cowpea for the production of dry and green grains found a mass of 100 dry grains of $20.6 \mathrm{~g} ; 20.2 \mathrm{~g} ; 20.8 \mathrm{~g} ; 24.7 \mathrm{~g}$ and $21.0 \mathrm{~g}$ for the Upanema, Umarizal, Itaú, Carnaubais and Baraúnas varieties, respectively, lower values than this research, except for the BRS potiguar variety. When Pereira (2014), when studying the optimization of the radish and cowpea consortium using BRS Itaim cultivar, fertilized with spontaneous species, found weight of 100 grains greater than $25 \mathrm{~g}$, with addition of $55 \mathrm{t} \mathrm{ha}^{-1}$ of flower-of -seda, which are similar to the aforementioned research.

According to Bertini et al. (2010), the grain size, usually evaluated through the weight of 100 grains, is one of the most important agronomic characters for product price formation. According to Ehlers and Hall (1997), grain size is important because it directly influences productivity and, together with grain coloring, determines the quality of the product to be marketed.

According to Carvalho and Nakagawa (2000), the seeds of larger size were better nourished during its development, having a well formed embryo and with a greater amount of reserve substances, and consequently, the most vigorous ones. The greater amount of reserve increases the probability of success in establishing the seedling (Haig \& Westoby, 1991), since it allows the survival for longer in unfavorable environmental conditions.

Popinigis (1985) states that the size of the seed in many species is indicative of its physiological quality. Thus, within the same lot, the small seeds present less emergence of seedlings and vigor, as opposed to larger seeds. According to Silva and Costa (2003), seed sizes vary from very small (less than $20 \mathrm{~g}$ ) to large (more than $40 \mathrm{~g} / 100$ seeds). This variation, too, is related to the genotype.

Table 3. Evaluation of the length/width ratio, expressed in $\mathrm{mm}(\mathrm{RCD})$ and weight of one hundred seeds, expressed in $\mathrm{g}$ (PCS) as a function of creole varieties and cultivar BRS potiguar, cultivated in Northeast Brazil

\begin{tabular}{lll}
\hline Varieties of cowpea beans & Evaluation of the length/width ratio (ELW) & Weight of one hundred seeds (WHS) \\
\hline Owl & $1.73 \mathrm{~b}$ & $25.50 \mathrm{c}$ \\
Canapum & $1.24 \mathrm{~d}$ & $27.00 \mathrm{bc}$ \\
Lizão & $1.47 \mathrm{c}$ & $25.66 \mathrm{c}$ \\
Always green & $1.50 \mathrm{c}$ & $28.33 \mathrm{~b}$ \\
Cow's rib & $2.14 \mathrm{a}$ & $31.16 \mathrm{a}$ \\
BRS potiguar & $1.77 \mathrm{~b}$ & $19.66 \mathrm{~d}$ \\
\hline
\end{tabular}

Note. ${ }^{*}$ Means followed by the same letter in the column do not differ by Tukey test at the $5 \%$ probability level

There was a difference between the cultivars of cowpea for the characteristics of thousand seeds and number of seeds per kilo, being the Creole cow's rib variety, statistically superior to the other varieties for weight of one thousand seeds, with an average value of $312.46 \mathrm{~g}$. For the characteristic amount of seed per kilo, the cultivar BRS potiguar was statistically superior to the other varieties, containing 5099.16 units $/ \mathrm{kg}$ (Table 4). It is verified that the higher the number of seeds $/ \mathrm{kg}$, the lower the productive performance of the cultivar per unit area.

The weight of a thousand seeds is an important data that can provide an indication of the quality of the seeds, as well as generate information to calculate the seeding density (Brasil, 2011).

Ávila et al. (2013) studying three cultivars of cowpea, verified that the cultivar BRS Marataoã showed a higher number of seeds per kilogram and, consequently, lower seed weight among the evaluated cultivars.

These results demonstrate that the number of seeds per kilogram is inversely related to the weight of a thousand seeds, that is, the larger the seed weight the smaller the number of seeds per kilogram.

The cultivar BRS Potiguar, the average weight of one thousand seeds resulting from the various treatments ranged from 249.3 to 250.9 grams.

According to Abreu, Cansi, and Juriatti (2007), the use of creole varieties constitutes a low-cost alternative for small farmers, who holds knowledge of these Creole materials. 
Table 4. Evaluation of the weight of one thousand seeds, expressed in g (WTS) and quantity of seed per kilogram, expressed in units $/ \mathrm{kg}(\mathrm{S} / \mathrm{K})$ as a function of creole varieties and cultivar BRS potiguar, cultivated in Northeast Brazil

\begin{tabular}{lll}
\hline Varieties of cowpea beans & weight of one thousand seeds (WTS) & Quantidade de semente por quilo (QSK) \\
\hline Owl & $252.79 \mathrm{c}$ & $3987.38 \mathrm{~b}$ \\
Canapum & $269.15 \mathrm{c}$ & $3719.56 \mathrm{bc}$ \\
Lizão & $258.70 \mathrm{bc}$ & $3870.29 \mathrm{bc}$ \\
Always green & $282.65 \mathrm{~b}$ & $3542.25 \mathrm{~cd}$ \\
Cow's rib & $312.46 \mathrm{a}$ & $3206.76 \mathrm{~d}$ \\
BRS potiguar & $196.63 \mathrm{~d}$ & $5099.16 \mathrm{a}$ \\
\hline
\end{tabular}

Note. * Means followed by the same letter in the column do not differ by Tukey test at the $5 \%$ probability level.

\section{Conclusions}

There was a statistical difference between the cultivars of cowpea for the biometric characteristics studied.

The cultivar creole costa presented statistically higher values for seed length, length length ratio, weight of one hundred seeds and weight of one thousand seeds, with mean values of $11.37 \mathrm{~mm} ; 2.14 \mathrm{~mm} ; 31.16 \mathrm{~g}$ and $312.46 \mathrm{~g}$, respectively.

The BRS potiguar variety was statistically superior for the characteristic amount of seed per kilo, with a value of 5099.16 units $/ \mathrm{kg}$.

\section{Acknowledgements}

Special thank the Jitirana (Merremia aegyptia L.) Research Group committed to the study of spontaneous species of the Caatinga Biome as fertilizer source and the Department of Agronomic and Forestry Sciences the Federal Rural Semi-Arid University (UFERSA), for the support in the conduction of the project.

\section{References}

Abreu, L., Cansi, E., \& Juriatti, C. (2007). Avaliação do rendimento socioeconômico de variedades crioulas e híbridos comerciais de milho na microrregião de Chapecó. Revista Brasileira de Agroecologia, 2, 1230-1233.

Almeida, I. C. F. (2016). Eficiência do uso de fósforo em genótipos de feijão caupi (41f., Dissertação (Mestrado em Manejo do Solo e Água no Semiárido: Fertilidade do Solo e Adubação), Universidade Federal Rural do Semi-Árido, Mossoró, RN, Brazil).

Alves, E. U., Bruno, R. L. A., Oliveira, A. P., Alves, A. U., Alves, A. U., \& Paula, R. C. (2005). Influência do tamanho e da procedência de sementes de Mimosa caesalpiniifolia Benth. sobre a germinação e vigor. Revista Árvore, 29, 877-885. https://doi.org/10.1590/S0100-67622005000600006

Ávila, J. S., Rocha, P. A., Neto, A. C. A., Nunes, R. T. C., Lima, R. S., \& Morais, O. M. (2013). Germinação de sementes de feijão-caupi de diferentes cultivares. III Congresso Nacional de Feijão-Caupi, Recife.

Bertini, C. H. C. M., Almeida, W. S., Silva, A. P. M., Lima, J. W., \& Teófilo, E. M. (2010). Análise multivariada e índice de seleção na identificação de genótipos superiores de feijão-caupi. Acta Scientiarum, 32, 613-619. https://doi.org/10.4025/actasciagron.v32i4.4631

Brasil. (2011). Regras para análise de sementes (p. 399). Brasília: MAPA.

Carvalho, N. M., \& Nakagawa, J. (2000). Sementes: ciência tecnologia e produção (4th ed., p. 588). Jaboticabal: FUNEP.

CONAB (Companhia Nacional de Abastecimento). (2016). Perspectiva para a agropecuária (Vol. 2, pp. 1-155). CONAB, Brasília.

Ehlers, J. D., \& Hall, A. E. (1997). Cowpea (Vigna unguiculata L. Walp). Amsterdam: Field Crops Research, 53, 187-204. https://doi.org/10.1016/S0378-4290(97)00031-2

EMBRAPA (Empresa Brasileira de Pesquisa Agropecuária). (2006). Sistema brasileiro de classificação de solos (2nd ed., p. 306). Rio de Janeiro: Embrapa.

Embrapa Meio-Norte. (2018). Feijão-Caupi. Oferta e demanda brasileira. In AGRIANUAL (Ed.), Anuário Da Agricultura Brasileira (p. 317). São Paulo: Instituto FNP. 
Freire Filho, F. R., Ribeiro, V. Q., Rocha, M. M., Damasceno, E., Silva, K. J., Nogueira, M. S. R., \& Rodrigues, E. V. (2011). Feijão-Caupi no Brasil: Produção, Melhoramento Genético, Avanços e Desafios (p. 84). Teresina: Embrapa Meio-Norte.

Freitas, G. G. F. (2015). Potencial genético de variedades tradicionais de feijão caupi para a produção para a produção de grãos secos e verdes (60f., Dissertação (Mestrado), Universidade Federal Rural do Semi-Árido, Mossoró).

Haig, D., \& Westoby, M. (1991). Seed size, pollination casts and angiosperm success. Evolutionary Ecology, 5, 231-247. https://doi.org/10.1007/BF02214230

Kottek, M., Grieser, J., Rudolf, B., \& Rubel, F. (2006). Mapa mundial da classificação climática de Köppen-Geiger atualizada. Meteorologische Zeitschrift, 15, 259-263. https://doi.org/10.1127/0941-2948/2006/0130

Kronka, S. N., \& Banzato, D. A. (1995). ESTAT: Sistema para análise estatística versão 2.0 (p. 243). Jaboticabal: Funep.

Locateli, V. E. R., Medeiros, R. D., Smiderle, O. J., Albuquerque, J. A. A., Araújo, W., \& Souza, K. T. S. (2014). Componentes de produção, produtividade e eficiência da irrigação do feijão-caupi no Cerrado de Roraima. Revista Brasileira de Engenharia Agricola e Ambiental, 18, 574-580. https://doi.org/10.1590/S1415-4366 2014000600002

Marcos Filho, J. (2005). Fisiologia de sementes de plantas cultivadas (p. 495). Piracicaba: Fealq.

Nascimento, J., Faustino, M. N., Meneses, J. A. G., Silva, S. S., \& Carvalho, C. M. (2012). Crescimento inicial do feijão-de-corda preto sob diferentes condições de sombreamento e adubação nitrogenada. Inovari International Meeting, 2012, Fortaleza, CE. Anais... Fortaleza: Instituto de Pesquisa e Inovação em Agricultura Irrigada.

Pereira, M. F. S. (2014). Otimização do consórcio rabanete e caupi-hortaliça adubado com espécie espontânea (85f., Tese (Doutorado em Fitotecnia), Universidade Federal Rural do Semi-Árido, Mossoró, RN, Brazil).

Popinigis, F. (1985). Fisiologia da semente (p. 289). Brasília: AGIPLAN.

\section{Copyrights}

Copyright for this article is retained by the author(s), with first publication rights granted to the journal.

This is an open-access article distributed under the terms and conditions of the Creative Commons Attribution license (http://creativecommons.org/licenses/by/4.0/). 